\title{
PROPOSTA DE IMPLEMENTAÇÃO DE PLANO DE MARKETING PARA A LIVRARIA ARGUMENTO
}

Matheus Lima

TRABALHO DE CONCLUSÃO DE CURSO

CENTRO DE CIÊNCIAS SOCIAIS - CCS DEPARTAMENTO DE ADMINISTRAÇÃO

Graduação em Administração de Empresas 


\title{
PROPOSTA DE IMPLEMENTAÇÃO DE PLANO DE MARKETING PARA A LIVRARIA ARGUMENTO
}

\author{
Trabalho de Conclusão de Curso
}

Trabalho de Conclusão de Curso, apresentado ao programa de graduação em Administração da PUC-Rio como requisito parcial para a obtenção do titulo de graduação em Administração.

Orientador(a): Vivian Peuker

Rio de Janeiro Outubro de 2021. 



\section{RESUMO}

Lima, Matheus. Proposta de implementação de um plano de marketing para a livraria Argumento. Rio de Janeiro, 2021, 39 páginas. Trabalho de conclusão de curso Departamento de Administração. Pontifícia Universidade Católica do Rio de Janeiro.

A livraria Argumento foi fundada na década de 70 em meio a ditadura militar brasileira. Já viveu por muitos momentos distintos e hoje vive talvez o mais desafiador da sua história, a digitalização do mercado com grandes concorrentes. Portanto, ela enfrenta as adversidades de se manter atuante nesse setor cada vez mais digital. Ainda mais com a incorporação, pelas organizações, dos novos adventos tecnológicos e uso das redes sociais como ferramenta de venda e exposição da marca. Podendo se tornar uma eventual ameaça para os negócios daqueles que não seguem seu ritmo.

Com a chegada da pandemia devido ao Covid-19, essa migração do mercado foi amplificada, mas também vieram impactos tanto econômicos, políticos e sociais na forma como o mundo operava. Este evento apareceu como uma mudança repentina e drástica no rumo das operações de muitas organizações e de diversos setores da economia. Faz-se uso de suas projeções preliminares como um fator externo de análise. Por meio das entrevistas feitas com clientes e funcionários, associadas ao estudo das transformações mercadológicas, procura-se a compreensão de como são realizados esses novos hábitos de consumo e a importância das empresas se adaptarem rapidamente.

Este presente estudo teve como objetivo central, o desenvolvimento e implementação de estratégia no plano do marketing, que ajudem a ampliar a rede de clientes, obter um relacionamento e vínculo com seu público-alvo, criando um maior valor agregado para a marca e consequentemente convertendo em um aumento das vendas e participação no mercado de livros. Possibilitando desta maneira, que, a organização em questão, possa ter recursos para se manter nesse mercado, além de criar oportunidades para que esta venha a crescer de maneira saudável e natural.

E por último, as sugestões de ações propostas, estão de acordo com as capacidades e limitações da organização. Estas propostas têm o potencial de alterar a forma como a marca trata o seu relacionamento com o cliente e público-alvo, explorando novas alternativas de venda e entrega do produto ou serviço, e se estas forem aplicadas de forma coesa, a organização tem muito a ganhar.

Palavras-chave: Livros, Livraria, Argumento, Consumidor, Público-alvo, Marketing, Vendas 


\section{ABSTRACT}

Lima, Matheus. Proposal for the implementation of a marketing plan for the Argumento bookstore. Rio de Janeiro, 2021, 39 pages. Course completion work - Department of Administration. Pontifical Catholic University of Rio de Janeiro.

Argumento bookstore was founded in the 70 s amidst the Brazilian military dictatorship. It has lived through many different moments and today it lives perhaps the most challenging in its history, the digitalization of the market with major competitors. Therefore, it faces the adversities of remaining active in this increasingly digital sector. Even more so with the incorporation, by organizations, of new technological developments and the use of social networks as a sales and brand exposure tool. It could become an eventual threat to the businesses of those who do not follow its rhythm.

With the arrival of the pandemic due to Covid-19, this market migration was amplified, but there were also both economic, political and social impacts on the way the world operated. This event appeared as a sudden and drastic change in the direction of operations of many organizations and different sectors of the economy. Their preliminary projections are used as an external analysis factor. Through interviews conducted with customers and employees, associated with the study of market transformations, we seek to understand how these new consumption habits are carried out and the importance of companies adapting quickly.

This present study had as its main objective, the development and implementation of a marketing strategy that helps to expand the customer network, obtain a relationship and bond with its target audience, creating greater added value for the brand and consequently converting it into an increase in book sales and market share. This makes it possible for the organization in question to have the resources to remain in this market, in addition to creating opportunities for it to grow in a healthy and natural way.

And finally, the suggestions for proposed actions are in accordance with the organization's capabilities and limitations. These proposals have the potential to change the way the brand treats its relationship with the customer and target audience, exploring new sales and delivery alternatives for the product or service, and if these are applied in a cohesive way, the organization has much to gain .

Keywords: Books, Bookstore, Argumento, Consumer, Target Audience, Marketing, Sales. 


\section{SUMÁRIO}

1. INTRODUÇÃO

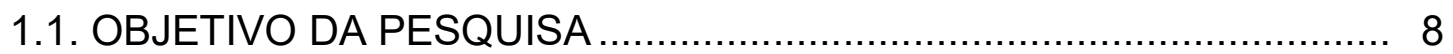

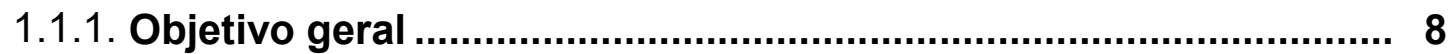

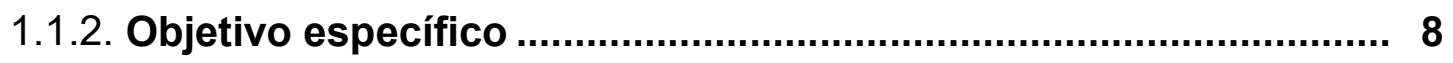

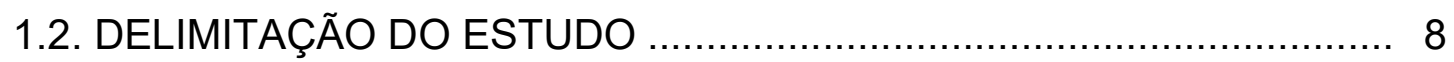

1.3. RELEVÂNCIA E JUSTIFICATIVA DO ESTUDO .................................. 8

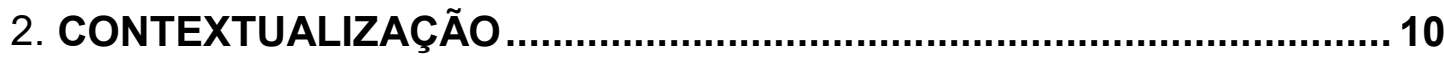

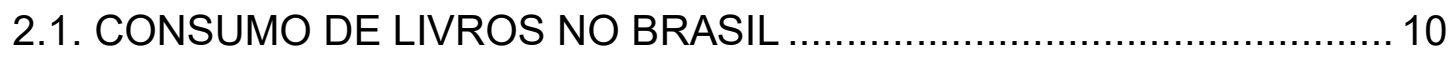

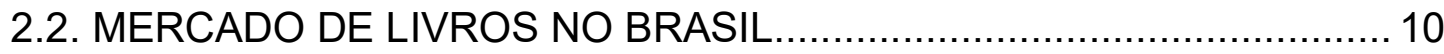

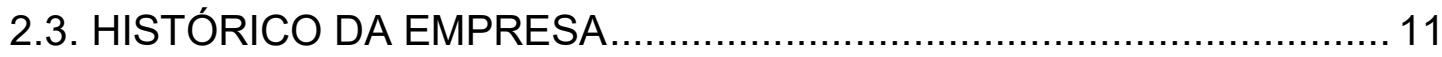

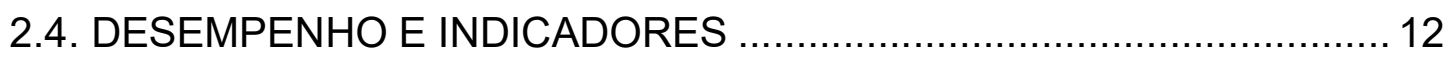

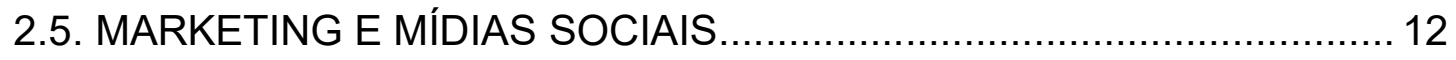

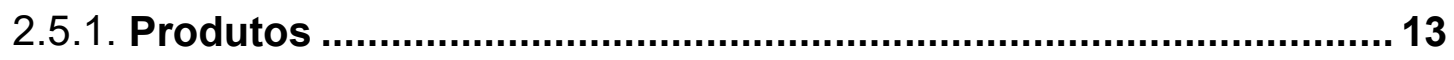

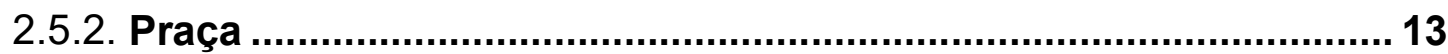

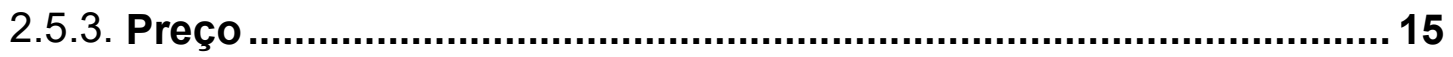

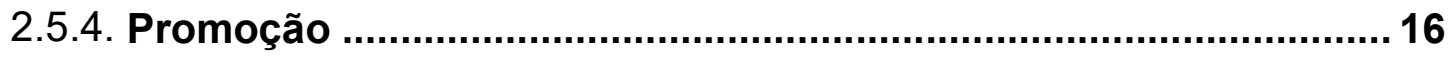

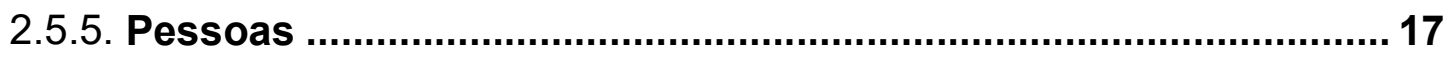

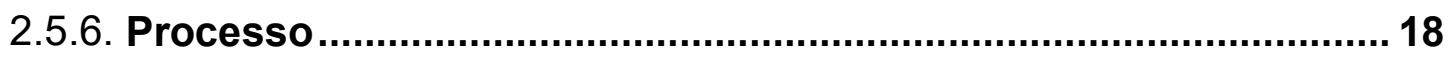

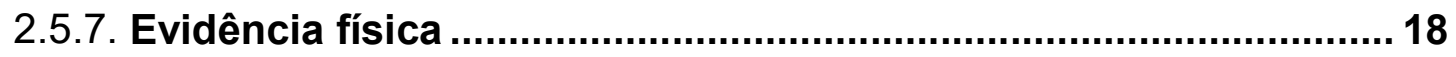

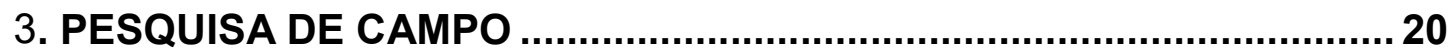

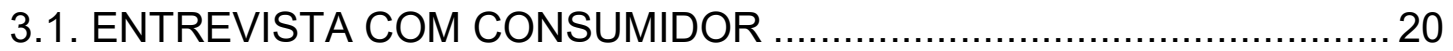

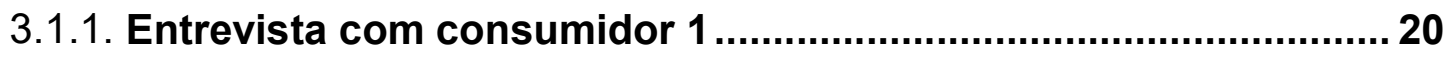

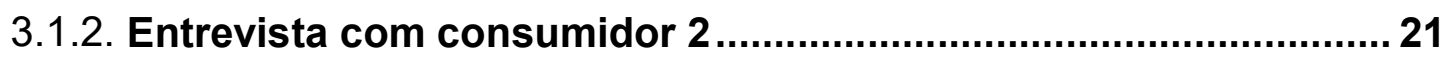

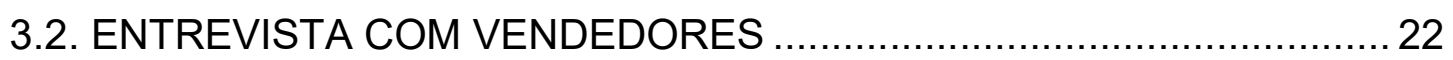

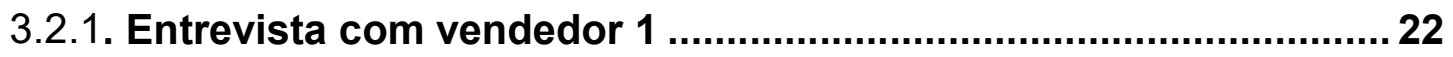

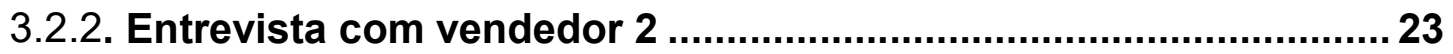

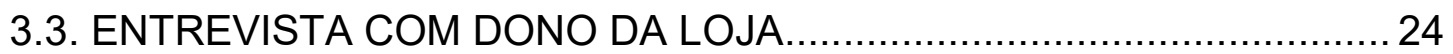

3.3.1. Entrevista com Marcus Gasparian ............................................. 24

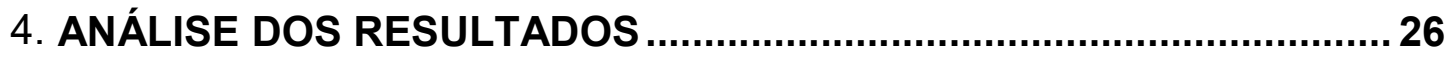

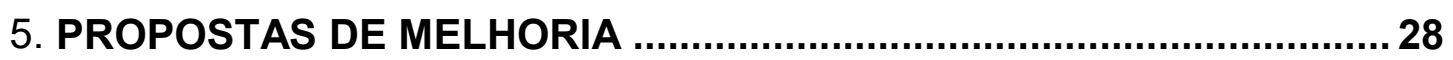




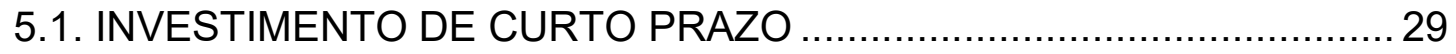

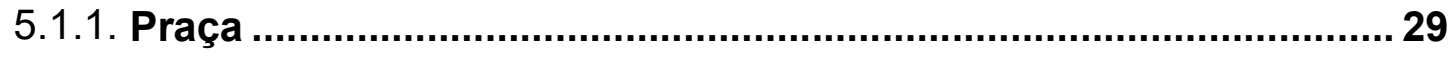

5.1.1.1. Presença em sites de vendas online........................................... 29

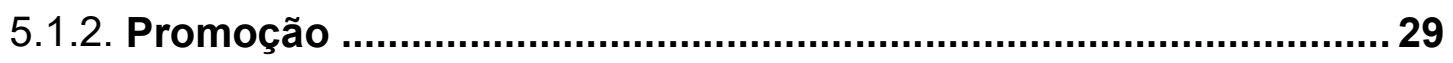

5.1.2.1. Aumentar o engajamento nas redes sociais ................................. 29

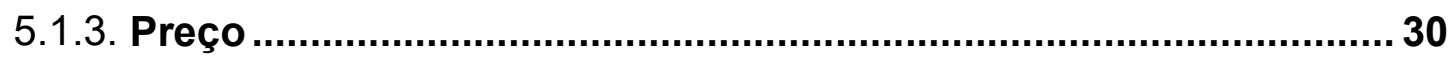

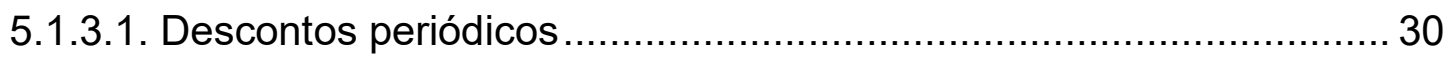

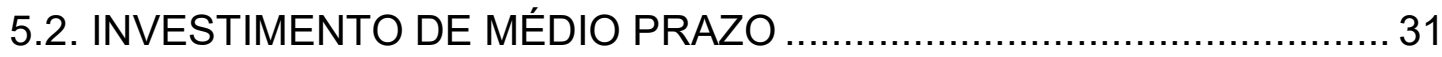

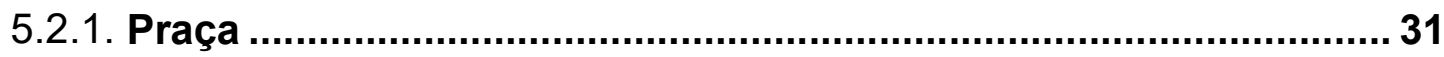

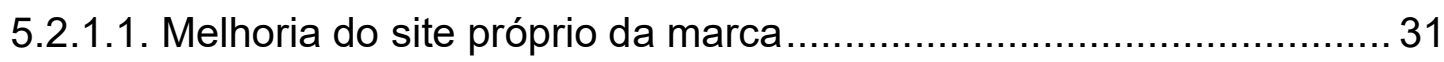

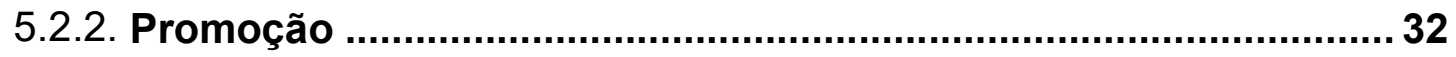

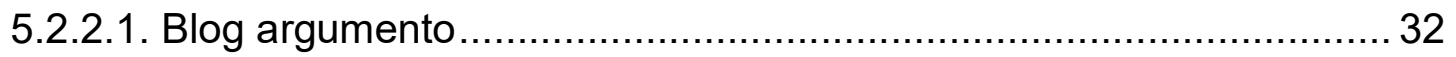

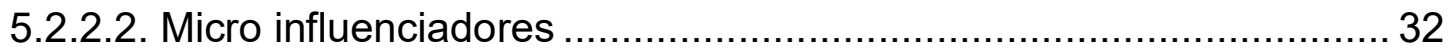

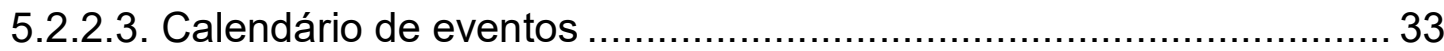

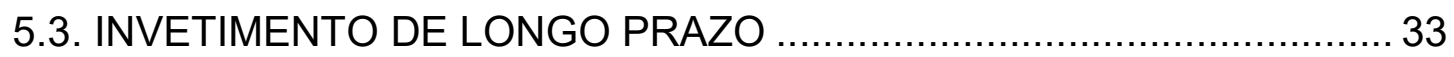

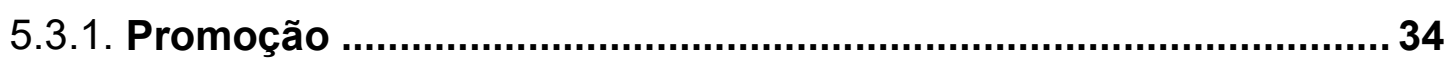

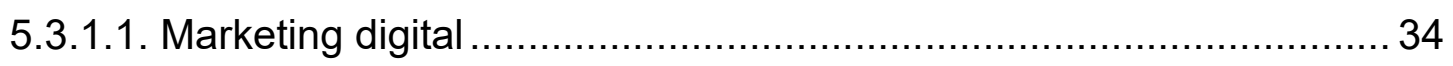

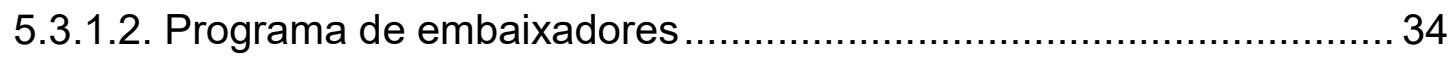

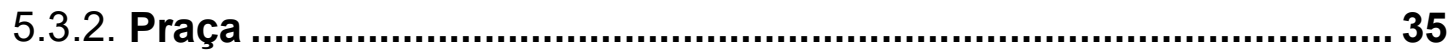

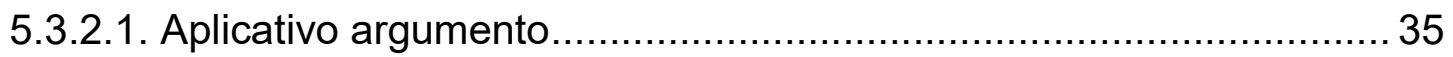

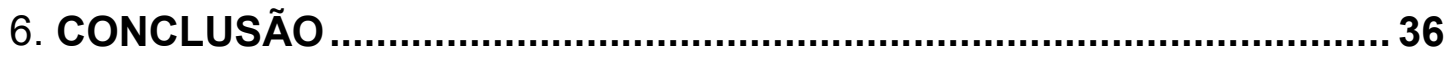

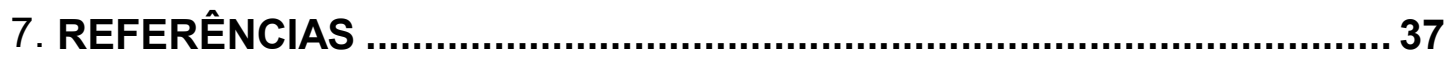

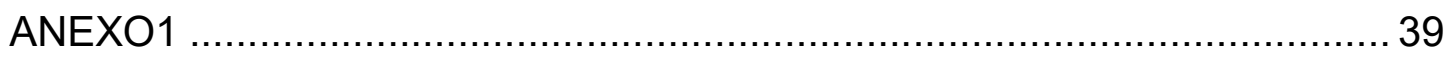

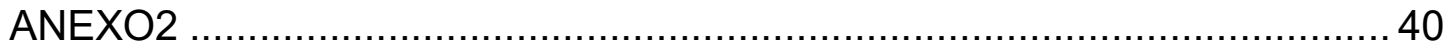




\section{Lista de figuras}

Figura 1: Imagem do interior da livraria Argumento.................................. 13

Figura 2: Imagem da fachada da livraria Argumento, no Leblon................... 14

Figura 3: Página da Argumento no site Estante Virtual. .............................. 14

Figura 4: Imagem do site da livraria Argumento. ..................................... 15

Figura 5: Imagem do Instagram da livraria Argumento. .............................. 17

Figura 6: Decoração interna da Argumento. .............................................. 19

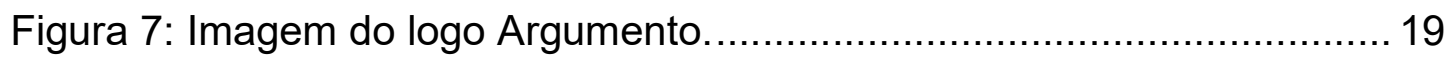




\section{INTRODUÇÃO}

O livro tem aproximadamente seis mil anos de história. A humanidade usou diversas formas de suas experiências com a intenção de contribuir para história e aprendizado das futuras gerações (CALDEIRA, 2002).

Segundo Aníbal Bragança, professor do Departamento de Estudos Culturais e Mídia da UFF e pesquisador em Produção Editorial, "A característica fundamental de um livro é ser portátil. Por isso não valem como livros as inscrições em rochas" (NOVA ESCOLA, 2021). Portanto, podemos considerar que as escrituras em tábuas de argila foram os primeiros modelos de livro.

Por volta de 2500 a.c. através de uma mistura de uma planta egípcia com couro surge o papiro. Este material ficou muito popular na época e facilitou a utilização dos livros, pois este ficara mais leve, facilitando o seu deslocamento. (NOVA ESCOLA, 2021). Outro marco para essa história é a invenção da prensa desenvolvida na década de 1450 pelo alemão Johannes Gutenberg (HISTORIA DO MUNDO, 2021). A sua invenção revolucionou a escrita em papel pois além de diminuir o tempo de produção, diminuiu também o custo de produção de exemplares e consequentemente o seu preço de venda.

No Brasil os primeiros livros só começaram a chegar com os colonizadores portugueses na década de 1500 (NOVA ESCOLA, 2021). Com a chegada da família real em 1808 fugida de Portugal por causa do conflito envolvendo a França de Napoleão Bonaparte, desembarcaram no Brasil cerca de 60 mil livros. Dois anos mais tarde, em 1810, Dom João VI criou no Rio de Janeiro a Biblioteca Real que mais tarde viria a se chamar Biblioteca Nacional, para abrigar todos esses exemplares (WIKIPEDIA, 2021). Esse movimento fez aflorar o desejo do povo brasileiro pela leitura e começaram a aparecer algumas livrarias pelo território nacional. Desta forma, começa a surgir o comércio de livros no país.

Em 1978 surge uma das mais notórias livrarias do Brasil e posteriormente da cidade do Rio de Janeiro, a livraria Argumento. Sua primeira localização foi a cidade de São Paulo e no ano seguinte abriu uma filial na cidade maravilhosa (LIVRARIA ARGUMENTO, 2021).

As duas lojas começaram a ficar famosas pela grande quantidade de livros na área das Ciências Sociais. Por ainda vivermos na época da censura da ditadura, estudantes, professores, jornalistas, escritores, artistas, políticos e grandes intelectuais encontravam seus livros nas prateleiras da Argumento. 
Atualmente eles contam apenas com a famosa loja do Leblon, na rua Dias Ferreira. A livraria já teve inúmeras noites de autógrafos dos principais autores e compositores e já serviu até de inspiração para Manoel Carlos criar um personagem de sua novela "Laços de Família", um livreiro.

\subsection{OBJETIVOS DA PESQUISA}

\subsubsection{OBJETIVO GERAL}

Esse estudo tem como objetivo final buscar alternativas no plano de marketing, para que seja possível um reforço no branding da livraria Argumento e que resulte numa maior divulgação da marca nos territórios onde ela atua e consequentemente aumente suas vendas.

\subsubsection{OBJETIVOS ESPECIFICOS}

Tais ações de marketing devem levar em consideração as limitações da marca, assim como suas forças e seus diferenciais, simultaneamente com as variáveis externas atuais. Para tal, são recomendados os objetivos a seguir:

- Reconhecer as principais limitações e desafios organizacionais;

- Identificar os principais canais de comunicação com o consumidor;

- Distinguir quais ações de marketing atingiram ou impactaram seu público-alvo.

\subsection{DELIMITAÇÃO DO ESTUDO}

Para a pesquisa proposta, será analisado como objeto de estudo, a participação da livraria Argumento no mercado local da Zona Sul, do Estado do Rio de Janeiro.

É importante evidenciar que o objeto de estudo e as pesquisas provenientes desse estudo, foram analisadas durante o segundo semestre de 2021, com auxílio do gestor da livraria.

\subsection{RELEVÂNCIA E JUSTIFICATIVA DO ESTUDO}


Portanto, esse estudo demonstra-se pertinente para qualquer pequena e média livraria, uma vez que procura identificar e sanar os obstáculos diários enfrentados pelas marcas desse setor. As ações de marketing propostas procuram oferecer estratégias que culminem em novas oportunidades, buscando aumentar a notoriedade da marca frente aos consumidores. E através disso, proporcionar uma experiência de consumo para render um aumento nas vendas.

É também relevante reconhecer as transformações tecnológicas, que aconteceram no mundo nas últimas décadas, e que culminaram em mudanças mercadológicas e como elas alteraram o hábito de compra do consumidor e seu entendimento da marca. Buscando trazer esse novo modelo de forma que venha a agregar valor às empresas. 


\section{CONTEXTUALIZAÇÃO}

\subsection{CONSUMO DE LIVROS NO BRASIL}

$\mathrm{Na}$ quinta edição da pesquisa Retratos da Leitura no Brasil (CENEPEC, 2021) realizada em 2019, ficou determinado que há no Brasil cerca de 100 milhões de leitores, que compõem $52 \%$ da população do país, com uma queda de cerca de 4,6 milhões de leitores, entre 2015 e 2019.

Crianças de 5 a 10 anos foi a única faixa etária que teve crescimento no número de leitores, de $67 \%$ (2015) para 71\% (2019). As faixas etárias de 14 a 17 anos e de 18 a 24 anos foram as que tiveram maior queda de cerca de 8 pontos percentuais.

$\mathrm{Na}$ pesquisa foram considerados leitores apenas aqueles que leram, inteiro ou em partes pelo menos um livro nos últimos três meses anteriores à pesquisa. Destes considerados leitores, $82 \%$ declararam que gostariam de ler mais, a maior causa para a nãoleitura entre esses foi a falta de tempo (47\%). Entre os não leitores, os principais fatores para a não-leitura foram a falta de tempo (34\%) e o fato de não gostarem de ler (28\%). Entre os leitores entrevistados, os dois principais usos do tempo livre são assistindo televisão e usando a internet. É interessante observar como, com o passar dos anos, o uso da internet foi crescendo entre os entrevistados.

O site G1 traz uma outra pesquisa que mostra que a média de livros inteiros lidos em um ano é de 4,2 livros por pessoa e a região Norte teve a maior porcentagem de leitura no país. O Centro-Oeste registrou o pior índice: Norte (63\%), Sul (58\%), Sudeste (51\%), Nordeste (48\%) e Centro-Oeste (46\%). Falando de autores lidos pelo povo brasileiro, Machado de Assis, Monteiro Lobato e Augusto Cury foram os autores preferidos do público. Entre os 15 autores mais citados, há apenas quatro mulheres: Zibia Gasparetto, Clarice Lispector, Jk Rowling e Agatha Christie.

\subsection{MERCADO DE LIVROS NO BRASIL}


Segundo o levantamento de dezembro de 2021 feito pela Nielsen Bookscan para o Sindicato Nacional dos Editores de Livros (NEXOJORNAL, 2021), o cenário da pandemia do Covid 19 afetou o mercado de livros, a previsão era de que o mercado de livros teria uma queda de vendas em 2020. Apesar da previsão o consumo de livros teve um pequeno crescimento, foram vendidos em 2020, 41,91 milhões de livros, um aumento de $0,87 \%$, em relação ao ano anterior.

O mercado livreiro movimentou $\mathrm{R} \$ 1,74$ bilhões em 2020 com uma queda de 0,48\%, em comparação com o ano de 2019. Essa redução pode estar ligada não só com a pandemia, mas com o crescimento do mercado de livros digitais que em geral são mais baratos.

A pesquisa da Nielsen ainda traz mais alguns dados sobre consumo de livros no país. O livro "como ficar rico?" impulsionou as obras mais vendidas de 2020. Neste mesmo ano a obra do youtuber brasileiro Thiago Nigro, "Do mil ao milhão", que ensina uma forma de alcançar a independência financeira, foi o livro mais vendido. Apesar disso, os livros com o tema de autoajuda financeira e pessoal perderam espaço para livros que abordam sobre racismo e política.

\subsection{HISTÓRICO DA EMPRESA}

Primeiramente, iremos apresentar um breve histórico da empresa, a partir das informações diretamente fornecidas pelo atual dono da Argumento, Marcus Gasparian.

A história da Argumento começa na década de 70 no meio da ditadura militar brasileira, com a editora Paz e Terra. Por ser uma empresa que vendia livros considerados de esquerda, muitas livrarias decidiram parar de comprar os seus exemplares. A partir daí o dono da editora, Fernando Gasparian, se viu na obrigação de abrir sua própria livraria. A loja começou em São Paulo e posteriormente passou para a cidade do Rio de Janeiro, na rua Dias Ferreira, no bairro do Leblon.

Em 1993, com a ideia de ter uma grande livraria onde o leitor poderia encontrar qualquer livro, a Argumento se muda para a loja que se encontra hoje, também na rua Dias Ferreira. Naquela época foi considerada uma das maiores lojas desse segmento na cidade, com um conceito vindo de Paris, França, de vender livros, com um pequeno restaurante ao lado. No caso da livraria carioca, o café Severino fica nos fundos, e além de livros vendia CDs e DVDs. A Argumento passa a ganhar notoriedade através dos seus inúmeros eventos realizados. Foram diversas noites de autógrafos, lançamentos de livros e CDs, alguns até 
mesmo com shows musicais. Desta forma, a Argumento construiu a sua fama de ser uma charmosa livraria do Leblon.

Com a chegada da internet e dos sites de vendas de livros online, o setor teve uma grande mudança e a Argumento sentiu muito. Segundo Marcus, o seu negócio virou um "showroom não remunerado" desses sites. Os consumidores passaram a frequentar a livraria apenas para se consultar com os livreiros, pegar algumas dicas e recomendações, ver o livro fisicamente e no final, comprar na internet, onde o preço é mais vantajoso, em alguns casos o cliente no máximo toma um café.

\subsection{DESEMPENHO E INDICADORES}

Uma vez que a Argumento é uma pequena empresa e, portanto, está inscrita no Simples Nacional, ela não possui nenhuma obrigação legal na apresentação de relatórios contábeis padronizados. Para uma forma de monitoramento e visualização do cenário que a empresa vive, serão utilizados números de antes e depois da pandemia que foram disponibilizados para essa pesquisa.

A livraria vendia em média cerca de 20 mil exemplares por mês, com a chegada da pandemia esse número caiu para aproximadamente 13.400 livros por mês. Eles tinham cerca de 120 funcionários nas duas unidades, Barra e Leblon, nos dois negócios, café e livraria. Após a pandemia a loja da barra foi fechada restando apenas 27 profissionais na unidade do Leblon.

\subsection{MARKETING E MÍDIAS SOCIAIS}

A Argumento desde seu começo, na década de 70, não investiu muito em marketing. Durante aquela época os meios de divulgação eram extremamente caros. Desta forma o seu principal meio de comunicação e divulgação da marca, era através da experiência que o consumidor tinha na livraria e fazendo eventos para a divulgação de livros, com a finalidade de ter mídia espontânea trazendo movimento para dentro da loja. Noites de autógrafos e eventos culturais se tornaram uma característica que a livraria tem com muito orgulho e por muito tempo gerou o resultado esperado. 
Como ferramenta de análise do presente estudo, utilizaremos como base os 7 P's do composto de marketing, apresentando sua variedade de produtos e suas estratégias de praça, preço, promoção, pessoas, processos, e evidências físicas.

\subsubsection{PRODUTOS}

A livraria Argumento tem aproximadamente 35 mil livros com inúmeros estilos literários. Desde livros infantis até livros de astrologia, a variedade é imensa como podemos ver na imagem a seguir.

Figura 1: Imagem do interior da livraria Argumento.

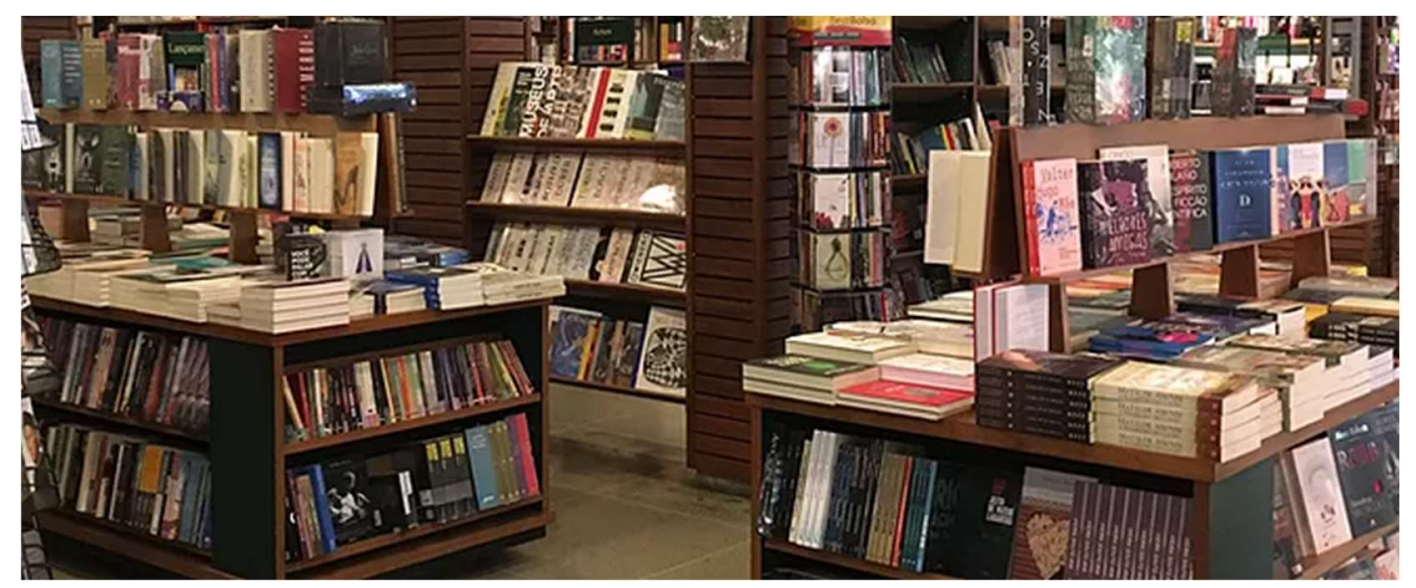

Fonte: Argumento (2021)

\subsubsection{PRAÇA}

A Argumento já teve uma loja em São Paulo e hoje se encontra apenas na cidade do Rio de Janeiro. Recentemente a loja da Barra da Tijuca foi fechada, restando apenas a Argumento do bairro onde começou na cidade na década 70, o Leblon. A seguir a foto da fachada. 
Figura 2: Imagem da fachada da livraria Argumento, no Leblon.

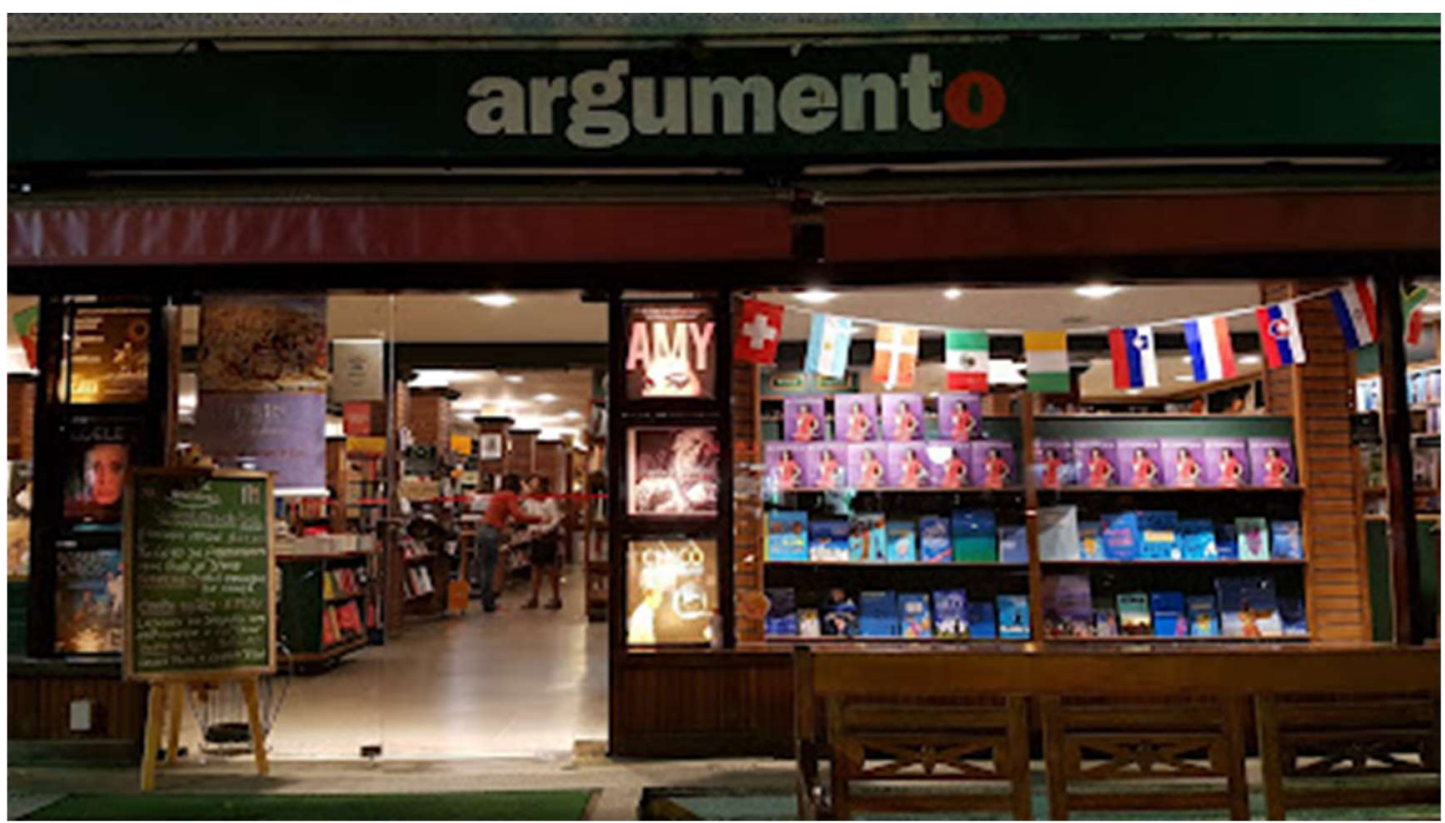

Fonte: Google (2021)

A Argumento utiliza alguns sites de e-commerce como praças de venda virtual, como por exemplo a estante virtual, como mostrado na figura 3 e a Amazon.

Figura 3: Página da Argumento no site Estante Virtual.

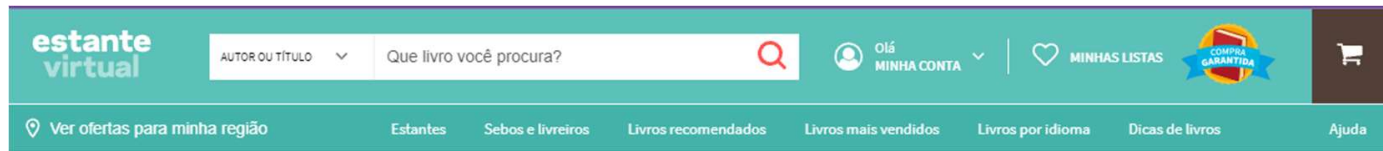

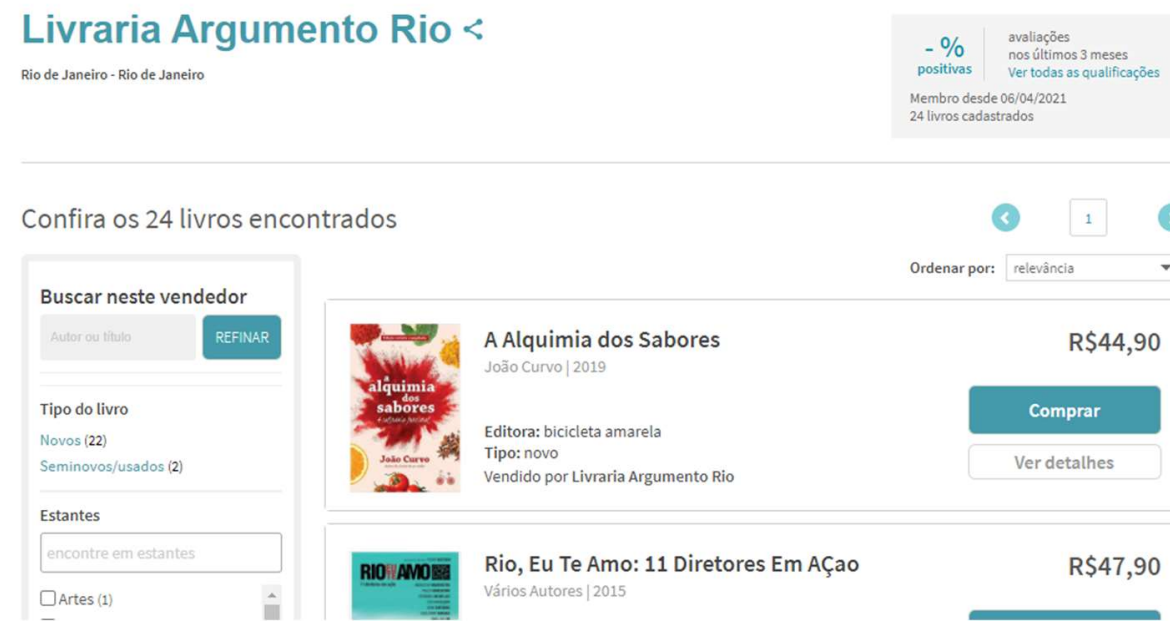

Fonte: Estante Virtual (2021) 
Outra forma que a empresa encontrou de espaço para venda de seus livros, principalmente após a pandemia do Covid 19, foi a venda através do seu próprio site como mostrado na figura 4.

Figura 4: Imagem do site da livraria Argumento.

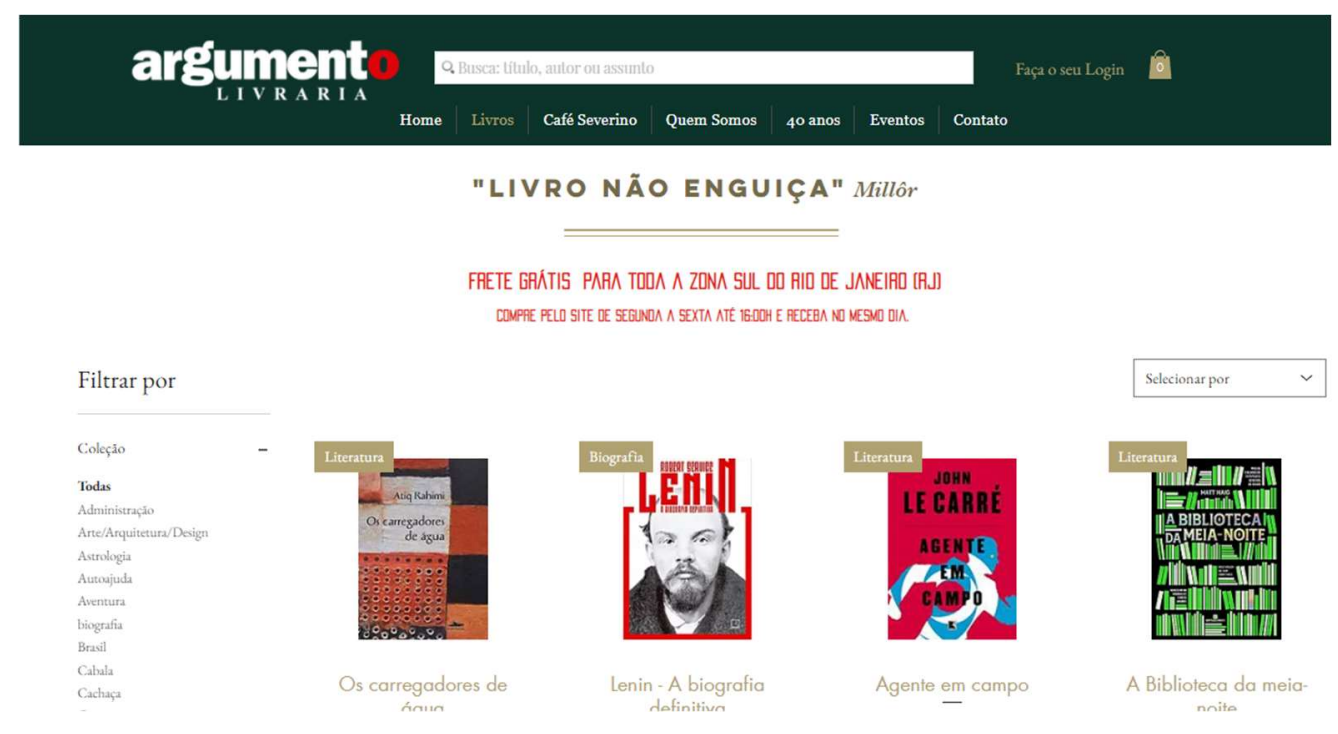

Fonte: Argumento (2021)

\subsubsection{PREÇO}

O preço é um dos pontos mais críticos do composto de marketing, uma vez que este trata da quantidade monetária ou unidade de valor que o consumidor está disposto a pagar pelo produto ou serviço. O valor percebido da oferta deve ser compatível ao valor ofertado no preço, caso contrário os consumidores buscarão outros produtos concorrentes. O preço costuma desempenhar um papel determinante na escolha de um produto para os consumidores e mantém-se como um dos principais pontos para se determinar a rentabilidade de uma organização e sua participação de mercado (SIQUEIRA, 2005).

No mercado de bens de consumo, devido à abundância de preços e tamanhos dos produtos, os consumidores voltam-se ao preço como um fator de garantia de qualidade do produto. Os consumidores tomam suas decisões de compra com base no consenso de mercado que oferece um produto no qual eles têm condições de pagar e tem a percepção que um preço inferior a este, significa uma qualidade inferior para aquele produto (SIQUEIRA, 2005).

Portanto, podemos verificar que o preço aplicado pela Argumento, é compatível com as demais livrarias do país. O preço acaba por ser acima do praticado por empresas de e- 
commerce, em virtude dos seus descontos promocionais. Porém em comparação às lojas físicas, os preços encontram-se ainda competitivos.

\subsubsection{PROMOÇÃO}

Atualmente, por causa da pandemia, não está havendo uma grande estratégia de promoção. A única forma que a marca utiliza para ainda se comunicar com os seus clientes e manter a relação que sempre teve, é através do Instagram, como mostrado na figura 5. A rede social não era prioridade para a livraria, porém com a chegada da pandemia eles se viram na necessidade de utilizá-la. Durante o período de reclusão, a estratégia encontrada para o uso da plataforma foi postar alguns vídeos de recomendações dos livreiros. Essa estratégia deu tão certo que ainda é utilizada.

Um artifício utilizado por Marcus, dono da loja, neste período, que gerou um resultado inesperado, foi utilizar o seu cachorro pessoal como mascote nas publicações do perfil da livraria. Segundo ele, quando um story era postado sem o seu fiel amigo, eles tinham cerca de 50 visualizações. Porém, quando o cachorro estava presente esse número subia para cerca de 200, 300 visualizações. Como podemos ver na figura 5 ele tem uma presença marcante na rede social da loja. 
Figura 5: Imagem do Instagram da livraria Argumento.

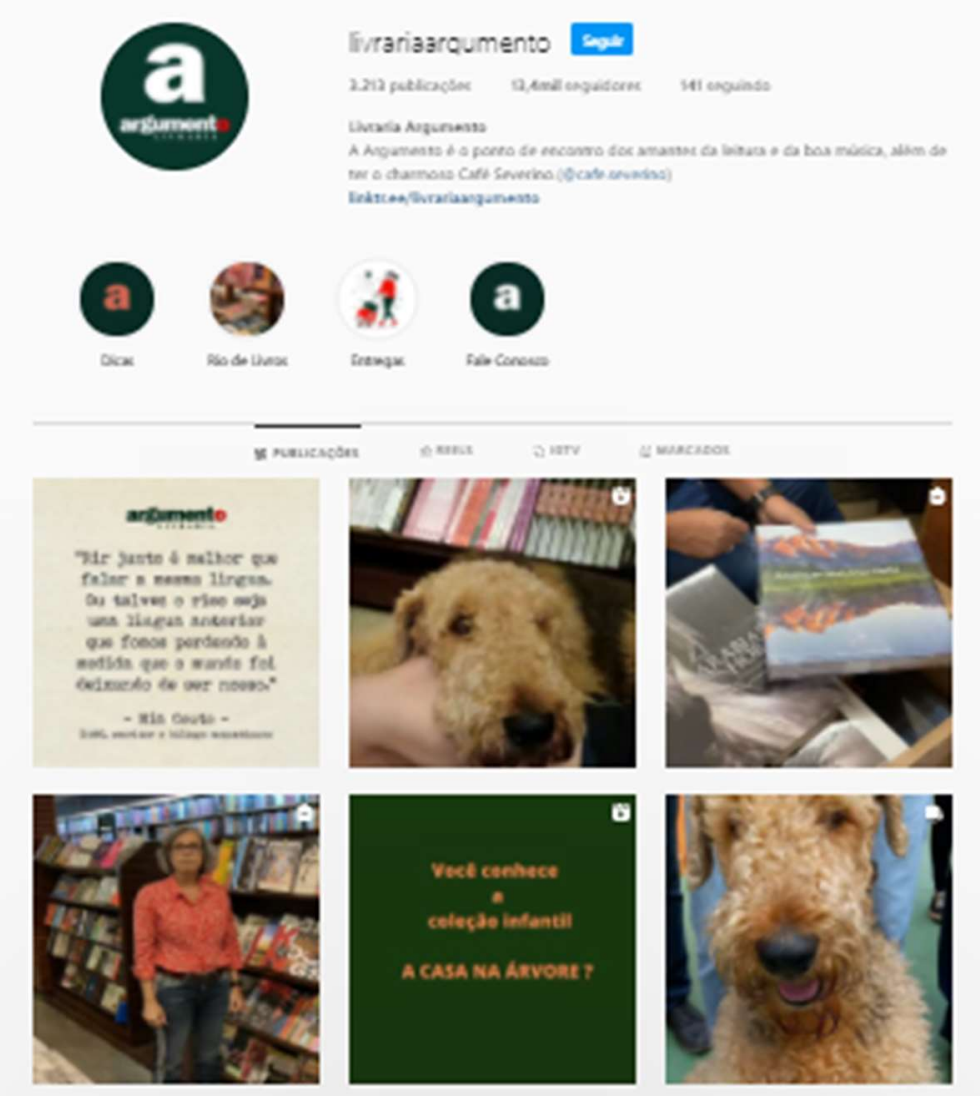

Fonte: Instagram (2021)

Outra forma que a Argumento utiliza como meio de promoção é o seu site. Apesar de hoje estar sendo usado mais como estratégia de venda dos seus exemplares, ele sempre foi um meio de comunicação da marca com o público em geral, seja ele consumidor ou imprensa.

Por conta da pandemia, a Argumento não está podendo fazer os seus famosos eventos e as noites de autógrafos. Contudo, quando esse período passar e as restrições não estiverem mais em vigor, eles pretendem voltar com a estratégia que fez a livraria ficar famosa e conhecida durante todos esses anos.

\subsubsection{PESSOAS}

A grande maioria das lojas do segmento contam apenas com uma equipe de livreiros. $\mathrm{Na}$ Argumento o time é dividido entre livraria e café, ao todo são 50 profissionais. A equipe de livreiros é formada por funcionários prontos para poder dar qualquer ajuda ou sugestão para 
os clientes a respeito de livros, tanto presencialmente nos corredores da loja, como pelo WhatsApp oficial da livraria.

\subsubsection{PROCESSO}

O processo de venda da livraria é simples, o cliente entra escolhe o seu livro na prateleira e paga, em alguns casos pode pedir ajuda a algum dos livreiros espalhados pela loja. Já o processo de venda através do site é um pouco diferente. O cliente escolhe o livro e paga de forma online. Após receber a informação a loja se prepara para realizar a entrega. As entrega para a zona sul da cidade do Rio de Janeiro, é feita pela própria loja, caso contrário, a entrega é através dos correios. Os pedidos que têm como destino a região de entrega da própria Argumento, feitos de segunda a sexta até as 16 horas, são recebidos no mesmo dia.

\subsubsection{EVIDÊNCIA FÍSICA}

Como principal evidência física da loja podemos citar o ambiente criado pela sua arquitetura. Como pode ser notado na figura 6, a decoração é toda em madeira, desde os pilares de sustentação até as prateleiras onde os livros são expostos. Os detalhes em verde musgo, cor da identidade visual da marca, como podemos observar na figura 7 , estão presentes por toda a loja. 
Figura 6: Decoração interna da Argumento.

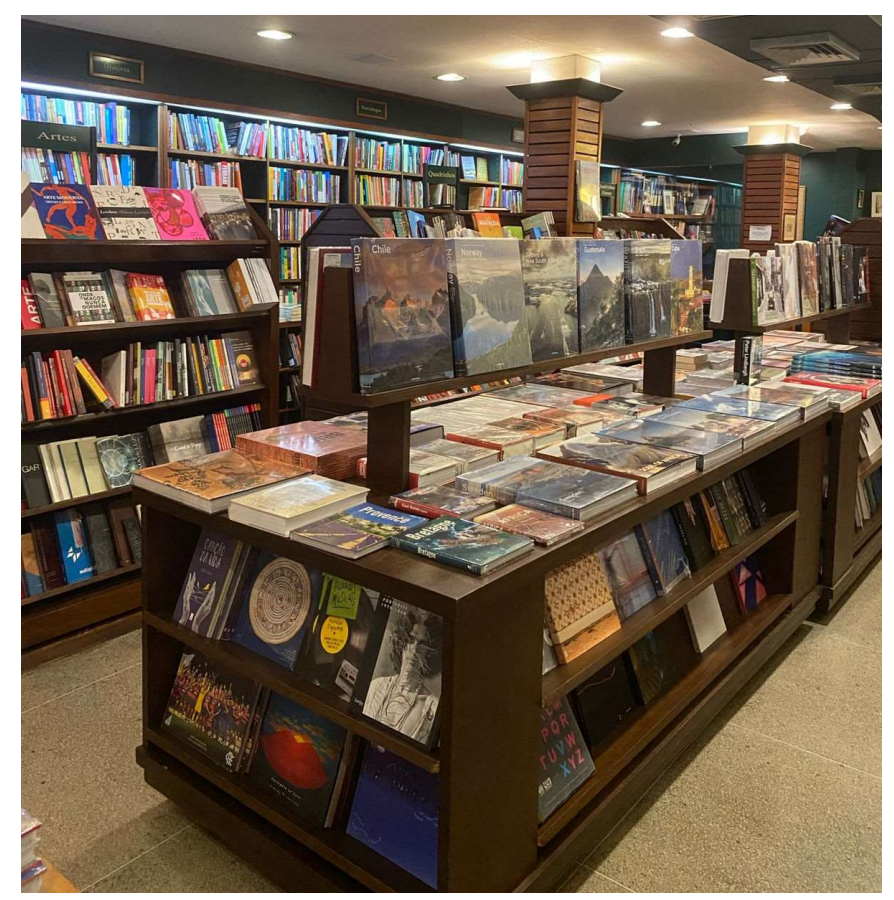

Fonte: Própria (2021)

Figura 7: Imagem do logo Argumento.

\section{argiument}

Fonte: Argumento (2021)

Outro meio utilizado para criar essa atmosfera da livraria é o famoso café Severino. O restaurante que fica nos fundos da loja, serve quase todos os tipos de comida e bebidas para todos os horários, café da manhã, almoço, lanche e até jantar. 


\section{PESQUISA DE CAMPO}

Por meio deste capítulo, serão apresentadas as entrevistas feitas ao longo do período de pesquisa de campo, realizadas com consumidores, vendedores e o dono da marca.

\subsection{ENTREVISTA COM CONSUMIDORES}

As entrevistas com os consumidores da livraria Argumento foram feitas através de entrevistas individuais semiestruturadas, com o objetivo de identificar o perfil consumidor, seus hábitos de consumo e suas preferências.

Para isso, procura-se analisar e assimilar as diferenças competitivas da empresa e possíveis pontos a serem revisados e reavaliados, mediante as experiências dos consumidores.

\subsubsection{ENTREVISTA COM CONSUMIDOR 1}

Viviane Fernandez, a primeira entrevistada, tem 34 anos e mora em Ipanema, Zona Sul da cidade do Rio de Janeiro. Quando entrevistada, contou que prefere comprar livros de forma presencial, pois gosta de "sentir os livros e ler a sinopse". Além disso contou que ir à livraria é uma experiência, ver as capas e se interessar por algum novo exemplar.

Perguntado se já conhecia a Argumento, a entrevistada disse que conhecia desde pequena, pois sua mãe sempre frequentava o bairro e a levava inúmeras vezes para a loja. Contudo, por conta da pandemia, Viviane deixou de frequentar a livraria, mas disse que pretende voltar a visitá-la.

Ao ser perguntada onde costuma comprar livros, a resposta foi: "depende, se quero um livro específico procuro na internet para ver onde está mais barato, mas se eu não sei que livro quero, ou estou em dúvida entre dois ou mais, vou a uma livraria."

Quando perguntada sobre a sensação ao entrar na Argumento, Viviane disse "eu me sinto como se esse fosse o meu momento de relaxar e ler e procurar o livro que eu quero e gosto". Afirmou também que sente que a decoração tem um tom mais rústico, aconchegante.

Foi perguntado se compraria em uma livraria desconhecida, a entrevistada disse que sim e em seguida perguntei quais os motivos a levariam a entrar em uma livraria 
desconhecida. Viviane disse "não tem muitos motivos de fazer eu entrar em uma livraria, se ela estiver em um lugar que eu frequento e eu julgar que ela é arrumadinha, bonitinha, eu vou entrar".

Perguntei dos livreiros, se ela já tinha se consultado com algum e a resposta foi sim, em seguida, perguntei se eles ajudaram ela na decisão de compra e ela respondeu "sim, uma vez um livreiro me recomendou uma trilogia, comprei o primeiro livro. Gostei tanto dele que no dia seguinte comprei os outros dois livros".

Quando perguntado se já usou o Instagram ou algum site como forma de sugestão Viviane disse que sim, segue uma blogueira nas redes sociais que dá dicas de livros. Em seguida perguntei se promoções e eventos (culturais ou uma simples noite de autógrafo) ajudariam ou facilitariam na hora da decisão de qual livraria frequentar e ela respondeu que não, isso não ajudaria, pois ela prefere ir em uma que seja perto de sua casa, onde se sinta bem. Mas completou dizendo que "se for uma promoção realmente muito boa pode me influenciar a comprar". Por fim perguntei se ela se diz fiel a alguma livraria ou site que venda livros e ela disse que não.

\subsubsection{ENTREVISTA COM CONSUMIDOR 2}

Dário Martins foi o segundo entrevistado, tem 64 anos e mora no Leblon, Zona Sul da cidade do Rio de Janeiro. Quando entrevistada contou que prefere comprar livros de forma presencial, pois não gosta de fazer compras online.

O entrevistado mora muito próximo da livraria desde o início dos anos 2000, portanto conhece muito bem a Argumento e já frequentou inúmeras vezes. Assim como a entrevistada anterior, ele parou de ir a livraria por causa da pandemia, mas está voltando a frequentar aos poucos.

Quando perguntado sobre a sensação ao entrar na livraria, Dário disse "sempre gostei da decoração daquele lugar, sempre me senti muito bem, tomar um cafezinho ler um livro, muito bom". Em seguida perguntei onde ele costuma comprar livros, a resposta foi "não tenho um lugar fixo onde compro livros, eu vou muito a Argumento pois é do lado da minha casa, mas as vezes compro naquela do Shopping Leblon, a Travessa".

Perguntei se ele compraria em uma livraria desconhecida e Dário me disse que compraria, mas não vê necessidade já que segundo ele tem duas excelentes livrarias próximo a ele. Em seguida, perguntei sobre os livreiros, se consultou com algum livreiro alguma vez e se ajudou na sua decisão de compra. A resposta foi "sim, algumas vezes já me consultei com eles, mas eu prefiro procurar o livro por conta própria, ver as capas e as sinopses". 
Quando perguntado se usa ou já usou o Instagram ou algum site como forma de sugestão de livro, Dário disse que não usa redes sociais e não visita sites com esse tipo de conteúdo, mas segundo ele seria uma forma interessante de saber sobre livros. Depois perguntei sobre promoções e eventos (culturais ou uma simples noite de autógrafo) ajudariam ou facilitariam na hora da decisão de qual livraria frequentar Dário me respondeu que as promoções chamam muito a atenção dele, mas ele não procura saber onde tem as melhores e sobre os eventos ele disse que gosta muito e costumava frequentar.

Por último perguntei se ele era fiel a alguma livraria ou site de venda de livros, e ele me respondeu que não se diz fiel, mas que frequenta muito a Travessa e a Argumento, segundo ele são as suas preferidas.

\subsection{ENTREVISTA COM VENDEDORES}

As entrevistas a seguir foram realizadas com dois vendedores da livraria, os livreiros, e tem como principal propósito verificar como eles enxergam a Argumento e o atual cenário do mercado de livros.

\subsubsection{ENTREVISTA COM VENDEDOR 1}

O primeiro livreiro entrevistado chama-se Marcos Magalhães e já tem 18 anos de experiência na livraria e consequentemente no setor também.

Quando perguntado a respeito do mercado de livros o mesmo respondeu que "é um mercado difícil de triunfar", segundo ele nunca foi um mercado muito aquecido pois a população brasileira não consome muitos livros. Em seguida perguntei sobre o futuro, o entrevistado vê uma tendência muito forte dos concorrentes digitais dominarem o mercado, porém ele acredita que algumas livrarias como a Argumento possam sobreviver a esse movimento.

Quando perguntei sobre a pandemia e como o mercado foi afetado, ele respondeu que "o mercado já é difícil, a pandemia ainda colocou uma crise na economia, que afetou o mercado de livros e o mercado geral. Todo mundo consumindo pouco e saindo pouco".

Foi perguntado se o entrevistado achava que a Argumento havia superado os obstáculos da pandemia da melhor maneira. Marcos me respondeu que achava que sim, mas segundo ele, a livraria ainda está na "luta", "ainda não acabou”. 
Quando perguntado se na visão dele a Argumento ainda tinha o mesmo lugar no mercado que tinha há 10 anos atrás, ele disse que não. $O$ entrevistado comentou que tinha essa visão muito por causa dos concorrentes digitais, como a Amazon. Ainda segundo Marcos há um outro concorrente que não é do ramo digital, mas segundo ele conseguiu crescer muito nos últimos anos no Rio de Janeiro, a livraria Travessa.

Perguntei como a Argumento poderia se diferenciar da concorrência, Marcos disse "é uma coisa que a gente já faz. O nosso diferencial é o atendimento." Em seguida perguntei o que segundo ele mais chama a atenção do cliente, ele me respondeu que o atendimento que os livreiros dão e a arquitetura, segundo ele acolhedora, aconchegante.

Por último perguntei a respeito do público-alvo, se ele acha que a Argumento consegue atingi-lo. $O$ entrevistado disse que sim, e que segundo ele tem um público muito cativo, mas diminuiu um pouco por causa da pandemia.

\subsubsection{ENTREVISTA COM VENDEDOR 2}

O segundo livreiro entrevistado chama-se Francisco e tem apenas 4 meses trabalhando na Argumento, porém sempre trabalhou como livreiro.

Quando perguntado a respeito do mercado de livros, Francisco respondeu que achava que está passando por um período de transição, muitos consumidores migrando para o digital, porém ele ainda acredita que seja um mercado promissor.

Quando perguntei sobre a visão dele a respeito do futuro do mercado, ele comparou o rádio à época que surgiu a televisão: "falavam que o rádio ia acabar, e as rádios continuam. O livro vai continuar, ele vai só se adequar ao momento".

Quando perguntado sobre a pandemia e como ele achava que ela afetou o mercado ele respondeu "quem gostava de ir à livraria sentir o livro e ter a troca de opiniões com os livreiros foi afetado, durante a pandemia isso acabou". Segundo ele, o mercado está voltando, mas de forma diferente ao que era pré pandemia. Em seguida, perguntei se ele achava que a Argumento tinha superado os obstáculos da pandemia da melhor maneira e ele me respondeu "acredito que sim, tanto que ainda estamos aqui". Francisco disse também que foi um período muito difícil, mas que todos precisam se reorganizar para encarar o novo mercado do pós pandemia.

Quando perguntado se na visão dele a Argumento ainda tinha o mesmo lugar no mercado que tinha há 10 anos atrás, o entrevistado respondeu que sim que a livraria tem um grande peso no mercado, "quando fala de livraria Argumento é uma referência do bairro do Leblon". Quando perguntei sobre o diferencial da livraria, o entrevistado disse que na visão 
dele, o uso do Instagram com resenhas e conteúdos sobre os livros é uma coisa que eles não faziam, mas estão fazendo agora e ele vê com bons olhos.

Foi perguntado o que o entrevistado acha que mais chama a atenção dos clientes na livraria. Francisco me respondeu "entrar num lugar e ter uma pessoa para te indicar um livro". Ainda segundo ele a livraria é um lugar aconchegante que faz com que o consumidor queira ficar ali. Por último perguntei se ele achava que a livraria conseguia atingir o seu público-alvo. O entrevistado disse que sim, muita gente continua frequentando a loja e segundo ele ainda tem consumidores novos que procuram uma informação.

\subsection{ENTREVISTA COM DONO DA LOJA}

A entrevista a seguir foi realizada com o dono da livraria Argumento, e tem como principal propósito verificar como ele enxerga a sua organização e o atual cenário do mercado em que está inserido.

\subsubsection{ENTREVISTA COM MARCUS GASPARIAN}

O atual dono da livraria chama-se Marcus Gasparian, filho do antigo dono Fernando Gasparian. A Argumento hoje está sob os comandos da família Gasparian e desde os 18 anos, Marcus trabalha na livraria, passando por diversas funções, inclusive balconista.

A primeira pergunta foi a respeito da visão do entrevistado sobre o mercado de livros atualmente. Marcus respondeu que vê com preocupação, "O crescimento do mercado online está criando uma crise muito grande nas livrarias físicas". Segundo ele, esse movimento pode fazer com que o consumo de livros diminua, pois, as crianças e as pessoas vão parar de ter contato com os livros de forma física, "quando uma livraria física fecha, você perde esse polo de fomentação de leitura".

Quando perguntado sobre o futuro do mercado, o entrevistado respondeu que acredita que existem dois tipos de futuro, um bom e um ruim. O futuro ruim é o movimento de acabar com a maioria das livrarias físicas e só ter os varejistas online, acabando inclusive com a função dos livreiros e desta forma, diminuindo o consumo de livros. Em relação ao futuro bom Marcus disse: "Se a gente perceber isso a tempo com uma valorização, principalmente dos jovens, em relação ao comércio local, vendo a importância de gastar um pouquinho mais na compra de um livro, mas sabendo que tem ali uma livraria sempre à disposição, ai eu vejo um futuro bem promissor, convivendo muito bem varejo online e físico". 
Perguntei sobre como a pandemia afetou o mercado de livros e ele me respondeu que tiveram duas alterações. A primeira, segundo ele, foi o impacto em relação ao consumo, "por mais que as pessoas tenham ficado em casa e precisado de livros, e a gente ter levado livros até elas, o consumo diminuiu". Ainda segundo ele, as vendas online cresceram muito e a pandemia serviu para quebrar essa barreira. Muitas pessoas que tinham medo da compra pela internet não tiveram muita opção para comprar o seu livro. O outro ponto que o entrevistado conseguiu perceber de alteração no mercado, foi a venda de livros maiores. "Muita gente que estava presa em casa decidiu encarar um Guerra e Paz, Montanha Mágica, livros mais pesados, que a pessoa sempre dizia que não tinha tempo. Muitos livros grandes ou grandes coleções foram vendidos em quantidades que a gente não estava acostumado a vender".

Quando perguntado se a Argumento conseguiu superar os obstáculos da pandemia da melhor maneira, o entrevistado respondeu "não sei se da melhor maneira, mas estamos vivos, talvez pudéssemos ter feito um pouco mais". Ele menciona algumas medidas que poderiam ter sido tomadas no início da pandemia. A demora para entrada no mercado online e o fechamento da loja da Barra da Tijuca, que poderia ter sido mais cedo, são duas dessas medidas.

Quando perguntado se na visão dele a Argumento ainda tinha o mesmo lugar no mercado que tinha há 10 anos atrás, ele disse que sim e na visão dele a livraria está maior, pois muitos dos seus concorrentes fecharam. Em seguida, perguntei do diferencial da livraria em relação à concorrência, Marcus disse que se orgulha muito dos seus livreiros e o atendimento que eles dão aos clientes, além do grande acervo que a Argumento tem.

Quando perguntei o que ele acha que mais chama a atenção do cliente na livraria, o entrevistado me respondeu "o acervo, em seguida os livreiros e depois o ambiente". Por último perguntei se a livraria atingia o seu público-alvo e ele disse que ainda tem muita gente para conquistar. 


\section{ANÁLISE DOS RESULTADOS}

Utilizando as informações coletadas através das entrevistas realizadas acima, juntamente ao processo de análise do contexto em que a organização está inserida, chegamos a alguns resultados.

A queda no consumo de livros no Brasil e a entrada dos concorrentes digitais no mercado local, é visto como um problema para a Argumento. Isso ocorre muito pelo fato de os varejistas da internet conseguirem colocar um preço mais barato do que o praticado pela Argumento, visto que alguns exemplares conseguem ficar com $40 \%$ de desconto. Isso porque o consumidor geralmente é movido pelo dinheiro e se um vendedor está ofertando um produto com desconto agressivo, ele vai levar vantagem do seu concorrente. Esse movimento está sendo sentido não só pela Argumento, mas também pelo mercado de livros no geral.

Por outro lado, um ponto positivo que a livraria tem a seu favor, é seu ambiente, que de acordo com as entrevistas é muito bem explorado. Os clientes gostam do clima aconchegante e calmo que a livraria proporciona, lá se sentem acolhidos e esquecem que estão em uma loja. Até há relatos de clientes que frequentam a Argumento apenas para passear e ler um livro.

Além disso, a livraria Argumento tem como ponto forte o atendimento que é dado pelos seus funcionários que são muito bem treinados. Isso acontece porque a livraria tem como política, que é seguida à risca, dar assistência, mas deixar o cliente à vontade pela loja. Já que os livreiros ainda são peças-chaves em uma livraria, os clientes confiam nas suas sugestões que na maioria das vezes são convertidas em vendas.

Bem como, é de grande importância às pequenas e médias livrarias buscarem aumentar seus canais de negócio, dessa forma elas se aproximam do seu cliente e quebram as barreiras de atendimento ao consumidor. Portanto, nota-se que se torna cada vez mais necessário explorar novas formas de se comunicar e de entregar o seu produto ao seu cliente.

Contudo a Argumento demorou para se inserir no meio digital, já que essa pauta nunca foi amplamente discutida. As redes sociais e o seu site eram protocolares, o site não tinha uma atualização constante e não era uma plataforma de vendas, ou seja, não se obtinha venda e lucro direto, e o Instagram e o Facebook seguem a mesma linha.

A falta de uso dessas redes sociais pela marca atrapalhou um pouco sua comunicação e engajamento com seus clientes. Muitos consumidores utilizam essas redes sociais para se informar melhor a respeito da marca, descobrir sobre possíveis eventos e informações da 
marca em geral. Mas a falta de atualização dessas redes sociais gera uma desinformação ao consumidor.

Porém, durante a pandemia, eles se viram obrigados a explorar esse canal de comunicação. A estratégia que foi introduzida no início da pandemia pela marca é interessante e vista com bons olhos pelos consumidores. São postados vídeos dos livreiros da Argumento dando dicas de livros, seja ele um exemplar novo ou não. O site da marca passou por uma transformação nesse contexto, precisou deixar de ser um site informativo para um ecommerce, dessa forma abriu-se mais um meio de venda para a Argumento. Porém, ainda é um espaço que carece de melhorias e atualizações, para poder se tornar uma grande praça de venda digital e um meio de comunicação da marca com o consumidor.

Outro ponto negativo que a Argumento não fazia antes da pandemia, é o uso de plataformas digitais de venda. Durante o início das restrições, a livraria passou a vender seus exemplares em alguns sites como Amazon e Estante Virtual. Como forma de tentar obter alguma renda esse movimento foi feito às pressas e da maneira que a marca conseguiu naquele momento, mas poderia ter sido de outra forma se feito com mais tempo e organização.

A situação vivida a partir de 2020 afetou muito mercado como um todo, além da Argumento, que era famosa pelos seus eventos culturais e de lançamento de livros, e sentiu muito com as restrições. Vale ressaltar que os consumidores sentem falta desse tipo de interação que a livraria proporcionava com os autores. Além disso, a loja conseguia vender uma grande quantidade de livros, sem contar na repercussão na mídia que tal evento gerava. 


\section{PROPOSTAS DE MELHORIA}

Ante a análise detalhada tanto do ambiente interno como externo da organização e de suas principais capacidades e desafios, serão apontadas a seguir as propostas de melhoria e diferenciação para a livraria Argumento, o objeto de estudo.

Como visto anteriormente, o mercado está em profundas transformações. Novas tecnologias, entrada de novos concorrentes internacionais e nacionais com poderio de investimento muito maior e um novo hábito de consumo de livros. Portanto as livrarias que não se adequarem a esse novo mercado irão ficar para trás, levando-as a falências. As propostas de implementação do plano de marketing que serão apresentadas a seguir visam o reposicionamento da empresa no mercado, com uma nova proposta de marca e uma nova função na vida dos seus clientes, tanto da livraria física como da digital, fazendo com que uma praça complemente a outra.

A implementação do plano de marketing a seguir, conseguirá, nos próximos 10 anos, manter a empresa ativa e com faturamento que gere lucro, obter crescimento de renda e de lembrança de marca, além da renovação e do crescimento da base ativa de clientes.

Assim sendo, as sugestões de melhoria indicadas neste capítulo, tem como objetivo principal, o desenvolvimento da Argumento no mundo digital. Para que ela continue sendo uma empresa autossustentável, todas as suas ações deverão ser direcionadas para gerar um aumento no número de vendas de seus produtos. Porém, tentar assumir o papel de principal concorrente dos grandes varejistas digitais da atualidade, é uma estratégia arriscada e pouco efetiva. Dessa forma, o plano desenvolvido para a Argumento, faz com que a marca assuma um papel diferente do que vem assumindo nos últimos anos, a de conselheira do leitor. Para assim, aumentar a sua divulgação, resultando em um aumento do número das vendas.

A livraria física, não vai perder seu espaço na jornada de compra do cliente, visto que ela assume um papel muito importante na vida do consumidor e da população brasileira, é um lugar de disseminação de cultura, principalmente através dos eventos que a tornaram famosa. Desta forma será possível gerar movimento dentro da loja resultando em uma receita, para assim a Argumento se manter viva em um mercado cada vez mais digital.

As propostas referenciadas em seguida foram desenvolvidas atreladas a estratégia de desenvolvimento dos 7P's. Em ordem de evidenciar as prioridades de investimento para a organização em conjunto de suas atuais capacidades, as sugestões de melhoria serão 
divididas em propostas de curto, médio e longo prazo além de estar de acordo com a estratégia dos 7P's.

\subsection{INVESTIMENTO DE CURTO PRAZO}

A organização poderá utilizar os recursos que já dispõe para realizar esses pequenos investimentos e melhorias. Como são melhorias que não necessitam grandes investimentos, a organização está apta para realizá-los no curto prazo. A proposta para o curto prazo tem como foco organizar os meios digitais da livraria, que foram feitos ou aprimorados durante a pandemia.

\subsubsection{PRAÇA}

\subsubsection{PRESENÇA EM SITES DE VENDAS ONLINE}

A primeira sugestão a ser apresentada a Argumento será uma ampliação da sua presença em sites de varejo online. Como mostrado anteriormente, a Argumento já tem uma presença em marketplace de livros, como Amazon e Estante Virtual. Contudo, a ideia inicial é dar mais atenção a esta alternativa de método de venda e destinar parte de sua produção para venda em sites como os das grandes companhias como B2W, Via Varejo e Magazine Luiza. Isso porque, conforme demonstrado nos capítulos anteriores e também confirmado em informações coletadas durante as entrevistas, os consumidores têm cada vez mais utilizado ferramentas de vendas online para realizarem suas compras.

Vale ressaltar que uma forma para aumentar as compras e adesão dos clientes para uma maior participação nesses tipos de sites, é investir na implementação de cupons de descontos. Com esse incentivo, os clientes antigos tendem a voltar a consumir e possivelmente aumentar a base de novos consumidores.

Dessa forma, a organização estar presente nessas plataformas de venda é de extrema importância para a manutenção e crescimento contínuo da mesma. Isso acontece porque cada vez mais os hábitos de consumo sofrem mudanças e a organização deve se manter atenta em acompanhar essas mudanças do setor.

\subsubsection{PROMOÇÃO}

\subsubsection{AUMENTAR ENGAJAMENTO NAS REDES SOCIAIS}


Durante a entrevista com o Marcus, dono da loja, foi percebido que a livraria tem um grande problema em relação ao seu engajamento nas redes sociais, mais especificamente o Instagram. O engajamento do usuário com um perfil de uma marca, gera relação a partir da identificação e lembrança da mesma. Porém, vale ressaltar que esse aumento é fruto de uma série de publicações que geram um interesse contínuo dos seus seguidores e clientes a fim de ampliar sua presença de marca.

Logo a marca precisa ter uma maior presença digital, mantendo sua base de clientes atualizados sobre informações a respeito da livraria. Criar um maior vínculo e engajamento com os clientes por meio de posts que gerem interação dos usuários, demonstrando fatos interessantes e relevantes aos apaixonados por livros.

Uma forma de aumentar o engajamento é a cocriação de vídeos com os livreiros para indicação de livros, séries e trilogias, como já vem fazendo, já que são capazes de estimular o aprendizado sobre a cultura do segmento. Além de, é claro, conectar e incentivar os clientes a procurarem, entender e se familiarizar mais com os livros, a livraria e suas mais variadas coleções e estilos.

Além disso, a marca pode explorar as ferramentas do Instagram como as caixas de perguntas e enquetes a fim de gerar uma maior interação e aproximação entre marca e usuário. Um exemplo de post criativo, que a concorrência e outras marcas fazem, é a batalha de produtos, no caso da Argumento, batalha de livros. O perfil deve postar dois livros e os usuários votam em qual deles preferem, ou até mesmo, em qual deles poderia haver um desconto.

Esses progressos não aumentam apenas a boa propaganda para a marca, mas também incentivam uma espécie de educação e fomentam a missão da empresa de disseminar o conhecimento e a cultura da população.

\subsubsection{PREÇO}

\subsubsection{DESCONTOS PERIÓDICOS}

Durante as entrevistas e a análise da empresa, outro aspecto observado é que a empresa perde clientes para os grandes sites de varejo digital, em função dos descontos que são oferecidos. A Argumento é uma loja que não pratica descontos e preços agressivos em seus exemplares.

Tendo isso em vista, para atrair mais clientes sugere-se que a livraria desenvolva uma estratégia de preço, focado em desconto para a sua loja física e digital. A proposta visa dar 
descontos em livros e categorias estratégicas, capazes de gerar esse interesse do público sem comprometer o fluxo de caixa da empresa.

Como forma de complementar a proposta anterior, a sugestão é agregar a estratégia das redes sociais com a estratégia de preço. Com isso, publicações que informam descontos ou preços mais agressivos de produtos, geram mais engajamento e tráfego para o site oriundo das redes sociais.

\subsection{INVESTIMENTO DE MÉDIO PRAZO}

São investimentos de médio prazo aqueles que dependerão de outros fatores, como o aumento do faturamento da empresa, através das sugestões de melhoria a curto prazo, mencionadas anteriormente. Para que seja realizado esse investimento, é necessário que a empresa invista um valor mais elevado, de maneira que se possa realizar o que é proposto a seguir.

\subsubsection{PRAÇA5.2.1.2. MELHORIA DO SITE PRÓPRIO DA MARCADurante a análise} da empresa e das entrevistas foi constatado que o site próprio da livraria, possui algumas falhas e possíveis melhorias. Como ele foi feito durante a pandemia, não houve um planejamento prévio sobre a criação do mesmo, desta forma foi identificado que o ranqueamento dele em sites de pesquisa como o Google está baixo. A causa desse problema é o chamado SEO (Search Engine Optimization).

Segundo o site Alura, SEO é uma série de aprimoramentos feitos no código e no conteúdo de um site para que ele seja encontrado mais facilmente e melhor avaliado por algoritmos de mecanismos de busca. Ainda segundo o mesmo site, uma otimização eficiente posiciona o site em questão, no topo das páginas de resultado, como Google, podendo chegar até mesmo na primeira colocação. Quanto melhor for o ranqueamento, maior a chance de conquistar o clique do usuário.

Em vista disso, sugere-se que a empresa contrate um especialista em SEO para poder otimizar o site da melhor maneira. Desta forma o site da Argumento ficará em maior evidência quando o usuário pesquisar sobre livros ou até mesmo sobre a própria livraria, gerando assim mais tráfego online, podendo resultar em um aumento do número de vendas.

Como visto anteriormente, as pessoas são movidas e atraídas por dinheiro. Portanto, outra sugestão para gerar mais tráfego para o site é agregar a estratégia do site à estratégia de preço, fazendo descontos exclusivos para o e-commerce e descontos para novos usuários, 
atrelado a toda a estratégia de promoção de redes sociais, mencionado nas propostas anteriores. Desta forma, a livraria consegue aumentar a sua base de clientes ao gerar um tráfego maior.

\subsubsection{PROMOÇÃO}

\subsubsection{BLOG ARGUMENTO}

Outro aspecto observado foi que alguns consumidores de livros gostam de fazer uma pesquisa, mesmo que breve, sobre qual exemplar comprar. Essa busca tende a ser feita nas redes sociais ou então em sites de dicas e recomendações.

Com isso, a proposta de digitalização da Argumento visa também assumir um papel de conselheira na vida do consumidor digital. Desta forma a chave para a essa transformação seria a criação do blog Argumento, que não visa uma grande quantidade de exemplares vendidos de imediato, mas sim uma lembrança de marca e proximidade ao consumidor.

A ideia é usar a mesma estratégia que está sendo empregada atualmente nas redes sociais, os vídeos dos livreiros indicando livros, porém redigidos em textos. Com a finalidade de se obter receita através do blog, além de ao final de cada texto ter um link para a compra do livro no e-commerce da própria livraria.

Outra estratégia para o aumento da receita seria se filiar ao Google e ter espaços de anúncios do Google Adsense, essa é uma fonte de receita muito utilizada por diversas empresas. Segundo o próprio site da companhia, o Google AdSense é uma maneira de os editores ganharem dinheiro com conteúdo on-line. Ele relaciona anúncios ao seu site com base nos visitantes e no conteúdo disponível. Os anúncios são criados e pagos pelos anunciantes, como o valor pago não é sempre o mesmo, os ganhos são variáveis. A taxa de pagamento deles é de $68 \%$ de toda a receita que for gerada com o site.

\subsubsection{MICROS INFLUENCIADORES}

Com o aprimoramento das redes sociais e do site da livraria sugerimos também explorar a estratégia de micro influenciadores com foco nas vendas do e-commerce. Muitas empresas se utilizam dessa estratégia pois ela não gera prejuízo. Isso porque o influenciador digital irá receber um percentual sobre uso de um cupom nominal pelos usuários no site da Argumento, assim a loja só paga se houver venda.

Os micros influenciadores são aqueles influenciadores digitais que possuem entre 10 e 100 mil seguidores e inscritos em seus canais ou redes sociais. Geralmente, esses perfis 
possuem maior taxa de engajamento do que os grandes influenciadores, que contam com milhões de seguidores (WHOW, 2021). Portanto, a estratégia visa gerar promoção do site da marca dentro do seu nicho de consumidores, aumentando assim o tráfego do site e posteriormente a receita da empresa.

Por ser uma estratégia atrelada ao e-commerce da livraria, recomenda-se que seja implementada após as melhorias do site sugeridas anteriormente. Além disso, por se tratar de uma estratégia voltada para venda, a proposta desse tópico precisa estar em linha com a estratégia de preço, também previamente sugerida.

\subsubsection{CALENDÁRIO DE EVENTOS}

Outro ponto a ser abordado é que a Argumento é uma livraria que ficou conhecida pelos seus eventos, noites de autógrafos e eventos culturais dentro do seu estabelecimento no Leblon. Como visto na análise da empresa, esses eventos eram capazes de gerar receita e movimento na loja, além da repercussão positiva na mídia. Com as restrições impostas pela pandemia nos últimos anos essa estratégia se reduziu a zero, pois nenhum evento pôde ser realizado.

Com o fim iminente dessas restrições, naturalmente a realização desses eventos vai voltar a ser uma das prioridades da livraria, como sempre foi durante todos os seus anos de história. A proposta de melhoria em relação a esse tema é a divulgação de um calendário de eventos através de seu site e redes sociais. Desta forma é possível gerar conteúdo para os seus meios de divulgação e os seus clientes e seguidores ficarão sabendo dos eventos podendo se programar para estarem presentes.

\subsection{INVESTIMENTO DE LONGO PRAZO}

Esses investimentos de longo prazo são investimentos que não são prioridade da organização no exato momento, mas tem como objetivo ajudar na implementação do plano de marketing envolvendo os 7P's. Como a Argumento ainda precisa realizar investimentos mais essenciais para sua manutenção e crescimento no mercado, estas sugestões de melhoria serão de longo prazo, contudo importantes para a consolidação da marca no mercado.

\subsubsection{PROMOÇÃO}




\subsubsection{MARKETING DIGITAL}

O aumento das vendas através do e-commerce da Argumento, aumentará a base de clientes registrada. Desta forma, alinhada à estratégia de preço, sugerida anteriormente recomenda-se implementar uma estratégia de divulgação por e-mail e sms.

O uso do e-mail marketing é uma estratégia utilizada pela maioria das empresas de todos os segmentos, é um canal de venda que não tem mais a mesma importância que tinha a alguns anos atrás, porém ainda tem relevância nas estratégias de marketing, por isso é recomendado o uso dessa estratégia, com divulgação de ofertas e novidades no catálogo.

Como forma de complementar e agregar nas propostas de divulgação da marca no meio digital, é recomendado que a Argumento explore os canais de mídia paga, como o Facebook Ads e o Google Ads. O investimento nessas plataformas é variado e depende do quanto o anunciante está disposto a pagar e do seu objetivo de alcance.

Além disso, recomenda-se a contratação de um funcionário especializado nessas áreas para se obter o melhor resultado. Dessa forma a livraria conseguiria aumentar o seu raio de alcance, impactando mais clientes, gerando assim maior tráfego no site e levando mais clientes para a sua loja física.

\subsubsection{PROGRAMA DE EMBAIXADORES}

Conforme já citado, as redes sociais viraram a vitrine das lojas, e os embaixadores viraram a cara da marca. Eles têm a função de disseminar valores, posicionamento, propostas e soluções da marca. Os seus seguidores passam a se identificar e gostar da marca a qual ela é embaixadora.

Com isso, a proposta é implementar o programa de embaixadores, visando aumentar a lembrança de marca, consequentemente o tráfego no site e fluxo dentro da loja física. A sugestão é entrar em contato com um influenciador digital que se enquadra nos pré-requisitos para ser a cara da livraria no mundo digital e negociar um pacote de inserções nas suas redes sociais, com a finalidade de assumir o papel de embaixador da Argumento. Para isso, ele precisa ter mais de 100 mil seguidores e ser focado no universo de livros. Como um ótimo exemplo, pode-se citar o @book.ster com 325 mil seguidores. Ele tem uma interação com dicas e trocas diárias com seus seguidores por postagens no feed e stories se tornando uma ótima opção para esse cargo.

\subsubsection{PRAÇA}




\subsubsection{APLICATIVO ARGUMENTO}

Com a evolução da tecnologia, e principalmente da internet e dos smartphones, passamos a viver em um mundo onde as pessoas buscam cada vez mais praticidade e rapidez para realizar as suas tarefas diárias, sejam elas fazer compras ou realizar uma consulta médica. Essa busca ainda foi amplificada pela pandemia. Tendo isso em vista, os aplicativos de diversos segmentos com diversas funções se espalharam pelo mundo e se tornaram principais fontes de renda de algumas empresas.

Portanto, visando oferecer essa praticidade e velocidade para o cliente, a última proposta que será oferecida a Argumento é a criação do aplicativo Argumento. A ideia não é que ele substitua o site, e sim se torne mais uma plataforma de venda e informação, gerando assim mais renda. Nele o consumidor irá além de encontrar o e-commerce da marca, novidades sobre a loja ou sobre o mundo dos livros, o calendário de eventos da livraria física e o blog Argumento, como proposto anteriormente. Para a realização dessa proposta seria necessário a contratação de uma equipe especializada para desenvolver e manter a ferramenta em constante atualização. 


\section{CONCLUSÃO}

Após a execução do referido estudo, podemos concluir que o tema em questão é vasto e bastante pertinente, ainda mais para a economia brasileira. Nota-se que dentro desse meio, o varejista atua como um intermediário entre os produtos e o consumidor final, cumprindo um papel essencial entre essas duas relações de comércio.

Devido à atual competitividade do mercado de livros, é praticamente obrigatório um conhecimento amplo sobre o tema, e deve-se buscar tê-lo antes de se introduzir nesse setor, para assim se manter rentável e competitivo.

É fundamental para as organizações buscarem sempre a inovação e monitoramento do desenvolvimento tecnológico no setor e no modo de vida das pessoas, para que assim, não se tornem obsoletos e desatualizados. Esse é um ponto que deve ter bastante atenção, uma vez que os hábitos de consumo estão em constante transformação e os consumidores cada vez mais rigorosos e exigentes.

Ao realizar a coleta de dados e das informações por intermédio desta pesquisa, constata-se que as mesmas são relevantes para a orientação das estratégias de venda, performance e marketing da organização objeto de estudo. Deve-se apontar que, da mesma forma que os hábitos e formas de consumo sofrem mudanças, com elas chegam novas oportunidades e possibilidades de se diferenciarem, viabilizando novas formas de relações comerciais.

É importante destacar que as estratégias de implementação de um plano de marketing e suas propostas de melhoria, devem ser levados em consideração para a organização objeto de estudo. Para que assim esta seja capaz de expandir suas alternativas de venda, fazer-se mais presente aos consumidores como marca, melhorando seu branding e por conseguinte, aumentar seu faturamento nas vendas, na área em que atua.

O trabalho desenvolvido por meio desta pesquisa demonstrou uma necessidade de se realizarem novos estudos e que busquem investigar mais a fundo o tema em questão. Estes estudos devem ser cada vez mais incentivados e elaborados, em preferência pelo meio acadêmico, e expostos através da publicação dos resultados de suas respectivas pesquisas, servindo como uma forma de direcionamento ao público interessado. 


\title{
REFERÊNCIAS BIBLIOGRÁFICAS
}

\begin{abstract}
ALURA disponível em:
$<$ https://www.alura.com.br/artigos/qual-e-a-importancia-do-seo-para-o-marketing-deconteudo> Acesso em 23 de otubro de 2021
\end{abstract}

CALDEIRA, Cinderela. Do papiro ao papel manufaturado. № 24, 2002. Disponível em: <http://www.usp.br/espacoaberto/arquivo/2002/espaco24out/vaipara. php?materia=0varia> Acesso em 06 de maio de 2021

CEMEPEC disponível em: <https://www.cenpec.org.br/tematicas/retratos-da-leitura-no-brasilpor-que-estamos-perdendo-leitores>. Acesso em 27 de setembro de 2021

G1 disponível em: <https://g1.globo.com/pop-arte/noticia/2020/09/11/brasil-perde-46milhoes-de-leitores-em-quatro-anos-com-queda-puxada-por-mais-ricos.ghtml>. Acesso em 08 de junho de 2021

GERUDE, V. M. Hábito de consumo de livros. Rio de Janeiro, 2018. 64 p. Dissertação (Graduação em Administração) - Departamento de Administração: Pontifícia Universidade Católica do Rio de Janeiro.

LIVRARIA ARGUMENTO disponível em: <https://www.livrariaargumento.com/livrariaargumento>. Acesso em 27 de setembro de 2021

NEXO JORNAL disponível em: <https://www.nexojornal.com.br/expresso/2021/01/26/Quanto-o-brasileiro-leu-em-2020.-E-oque-mais-leu>. Acesso em 08 de junho de 2021

NOVA ESCOLA disponível em: <https://novaescola.org.br/conteudo/2547/quem-inventou-olivro>. Acesso em 06 de maio de 2021

OLIVEIRA, T. L. O consumo de livros impressos na era digital. Rio de Janeiro, 2015. 36 p. Dissertação (Graduação em Administração) - Departamento de Administração: Pontifícia Universidade Católica do Rio de Janeiro.

SIQUEIRA, A. C. B. Marketing empresarial: Industrial e de serviços. São Paulo: Saraiva, 2005

SOUSA, N. M. P. Análise dos fatores que influenciam o consumidor do Rio de Janeiro a escolher entre livros impressos ou digitais para lazer. Rio de Janeiro, 2015. 52 p. Dissertação (Graduação em Administração) - Departamento de Administração: Pontifícia Universidade Católica do Rio de Janeiro. 
SUPORTE GOOGLE disponível em:

<https://support.google.com/adsense/answer/6242051?hl=pt-BR> Acesso em 24 de outubro de 2021

WHOW disponível em:

<https://www.whow.com.br/vendas/microinfluenciadores-quem-sao-e-qual-a-suarelevancia/> Acesso em 24 de outubro de 2021

WIKIPEDIA

disponível

em:

<https://pt.wikipedia.org/wiki/Hist\%C3\%B3ria_do_livro_no_Brasil\#Per\%C3\%ADodo_Colonial $>$ Acesso em 06 de maio de 2021

WIKIPEDIA disponível em: <https://pt.wikipedia.org/wiki/Facebook> Acesso em 06 de maio de 2021

WIKIPEDIA disponível em: <https://www.historiadomundo.com.br/curiosidades/origem-doslivros.htm> Acesso em 06 de maio de 2021 


\section{ANEXO 1: QUESTIONÁRIO UTILIZADO PARA OS CONSUMIDORES NO ESTUDO DE CASO}

1. Você prefere comprar livros online ou de forma presencial? Por que?

2. Já frequentou ou conhece a livraria Argumento?

3. Em qual ocasião você conheceu a marca?

4. Você voltaria a frequentar a livraria?

5. Qual foi a sensação ao entrar na Argumento?

6. Onde você costuma comprar livros?

7. Você compraria em uma livraria desconhecida?

8. Por quais motivos você entraria em uma livraria desconhecida?

9. Você já se consultou com algum livreiro alguma vez? Se sim, te ajudou na decisão de compra?

10. Você usa ou já usou o instagram ou algum site como forma de sugestão de livro?

11. Promoções e eventos (culturais ou uma simples noite de autógrafo) ajudariam ou facilitariam na hora da decisão de qual livraria frequentar?

12. Atualmente você se diz fiel a alguma livraria ou site que venda livros? 
ANEXO 2: QUESTIONÁRIO UTILIZADO PARA OS LIVREIROS NO ESTUDO DE CASO

1. Como você vê o mercado de livros atualmente?

2. Como você acha que vai ser o futuro desse mercado?

3. Como você acha que a pandemia afetou o mercado de livros?

4. Você acha que a Argumento conseguiu superar os obstáculos da pandemia da melhor maneira?

5. Para você a Argumento ainda tem o mesmo lugar no mercado que tinha há 10 anos atrás?

6. Como a Argumento poderia se diferenciar da concorrência?

7. O que você acha que mais chama a atenção do cliente na livraria?

8. Você acha que a Argumento consegue atingir o seu público-alvo? 